\title{
A preliminary fertilization test on sorghum (Sorghum bicolor L. Moench) with three organic amendments of humus and domestic wastes
}

Una prueba preliminar de fertilización en sorgo (Sorghum bicolor L. Moench) usando tres mejoradores orgánicos elaborados con humus y desechos sólidos domésticos

\author{
Luis Guerrero-Cabrera ${ }^{1 *}$ (D), Miguel Angel Sánchez-Hernández ${ }^{1}$ (D)
}

\begin{abstract}
A preliminary study was carried out in order to assess the effectiveness of the compost as a sorghum fertilizer (Sorghum bicolor L. Moench), comparing it with two other organic amendments and chemical fertilization. Compost and the two amendments produced by fermentation of domestic organic wastes and humus (made it with agricultural and garden wastes), were produced in polyethylene bio-reactors of $200 \mathrm{~L}$ capacity, for 60 days. The fertilization test was applied under a randomized block design with one factor (fertilization treatment) in an experimental plot of sorghum plants (one month old). «Plant height» and «fresh weight» variables were recorded at the end of a three month trial period. The results of the study, analyzed by ANDEVA and Tukey test $(p \leq 0.05)$, showed that the «plant height» and the «fresh weight» obtained from plants fertilized with compost $(75.10 \pm 21.12$ $\mathrm{cm}$ and $0.876 \pm 0.162 \mathrm{~kg} / \mathrm{m}$ ), were significantly higher than those obtained by the control treatment of chemical fertilization $(51.40 \pm 19.30 \mathrm{~cm}$ and $0.460 \pm 0.22 \mathrm{~kg} / \mathrm{m})$ and those fermented organic amendments $(58.41 \pm 17.75 \mathrm{~cm}$ and $0.428 \pm 0.139 \mathrm{~kg} / \mathrm{m} ; 43.93 \pm 14.01 \mathrm{~cm}$ and $0.279 \pm 0.040 \mathrm{~kg} / \mathrm{m})(\mathrm{p} \leq 0.05)$. Finally, it is observed that domestic vegetable waste and humus are a good option as substrates for the production of compost due to its high availability and low cost.
\end{abstract}

Keywords: Sorghum bicolor L. Moench; organic amendments; compost; humus; vegetable domestic wastes.

\section{RESUMEN}

El presente estudio preliminar fue conducido para evaluar la efectividad de la composta como fertilizante en sorgo (Sorghum bicolor L. Moench), comparándola con otros dos mejoradores orgánicos y fertilización química. La composta y los dos mejoradores producidos por fermentación de desechos orgánicos domésticos y humus (elaborado con desechos agrícolas y de jardinería), fueron producidos en bio-reactores de polietileno de $200 \mathrm{~L}$ de capacidad, durante 60 días. La prueba de fertilización fue realizada bajo un diseño aleatorio de un factor (tratamiento de fertilización) por bloques, en una parcela experimental a plantas de sorgo (de un mes de crecimiento). Las variables «altura de la planta» $\mathrm{y}$ «peso fresco» fueron registradas al final de un periodo de prueba de tres meses. Los resultados del estudio, analizados por ANDEVA y prueba de Tukey $(\mathrm{p} \leq 0,05)$ mostraron que la «altura de la planta» y el «peso fresco» obtenidos de las plantas fertilizadas con composta $(75,10 \pm 21,12 \mathrm{~cm}$ y $0,876 \pm 0,162 \mathrm{~kg} / \mathrm{m})$, fueron significativamente mayores que aquellas obtenidas por el tratamiento control $(51,40 \pm 19,30 \mathrm{~cm}$ y $0,460 \pm 0,22 \mathrm{~kg} / \mathrm{m})$ y los mejoradores orgánicos fermentados $(58,41 \pm 17,75 \mathrm{~cm}$ y $0,428 \pm 0,139 \mathrm{~kg} / \mathrm{m} ; 43,93 \pm 14,01 \mathrm{~cm}$ y $0,279 \pm 0,040$ $\mathrm{kg} / \mathrm{m})(\mathrm{p} \leq 0,05)$. Se observa, finalmente, que los desechos orgánicos domésticos y el humus son una buena opción como sustratos para la producción de composta debido a su alta disponibilidad y bajo costo.

Palabras clave: Sorghum bicolor L. Moench; mejoradores orgánicos; composta; humus; desechos vegetales domésticos. 


\section{INTRODUCCIÓN}

It is known that organic amendments such as green manures, manures, compost, vermicompost and those produced by fermentation of several organic materials - such as plant debris from agricultural residuesand biofertilizers or microbial inoculants are an alternative to diminish the damages caused by chemical fertilization in the soil (Abbott et al., 2018). In order to differentiate biofertilizers, Vessey (2003) stated that a biofertilizer is any substance containing microorganisms capable to establish a symbiotic relationship with the plant, as part of its rhizosphere, in order to increase their growth by means of replacing soil nutrients, making nutrients more available or increasing plant access to nutrients.

Both organic amendments and biofertilizers can be applied separately or blended. For instance, due to the high concentration of nutrients and their capacity to enhance microbiological activity on soil, organic amendments as compost can be inoculated with isolated bacteria and fungi (Smith and Collins, 2007). In this trend, Singh and Sharma (2003) enriched composting and vermicomposting with Pleurotus sajor-caju (fungus), Trichoderma harzianum (fungus) and Azotobacter chroococcum (bacteria) to improve growth of mung bean (Vigna radiata). Another example in this current is the biodynamic preparation which, is a mix that contains nutrients, amino acids, growth promoting substances like indole acetic acid, and gibberellins stemmed from the fermentation process of cow dung, cow urine, milk, curd, and clarified butter (ghee). The biodynamic preparations also have a microbial diversity of bacteria like Sclerotium sp. and Bacillus cereus, besides beneficial fungal genera like Aspergillus, Rhizopus, and Trichoderma (Radha and Rao, 2014).

On the whole, there are two main groups of biofertilizers used and evaluated in plant bioassays and land plots as microbial inoculants: 1) the plant growth promoting rhizobacteria (PGPR) (Vessey, 2003) and 2) the arbuscular mycorrhizal fungi (AM) (Igiehon and Babalola, 2017). Most of the species of these groups are efficient as chemical fertilizers for improving plant growth and crop production; they were proved alone or mixed in tomato [Lycopersicon esculentum] (Altuhaish and Tjahjoleksono, 2014), maize [Zea mays L.] (Viti et al., 2010; García-Olivares et al., 2012), sorghum [Sorghum bicolor L. Moench] (García-Olivares et al., 2006). Hipolito-Romero et al. (2017) studied the effect of bacterial consortia inoculated in soil as biofertilizer on cocoa [Theobroma cacao L.] and soybean (Glycine max L.) was evaluated by Vessey (2003) and Igiehon and Babalola (2017).

It should be mentioned at this point that some species of PGPR and AM form part of a microbial community within fermented organic amendments and compost, and its dynamic depends on factors such as temperature, humidity, microbial interactions with microorganisms involved in decomposition, and earthworm participation (e.g. Eisenia foetida). Moreover, the diversity of substrates used in the process play an important role in the structure of microbial communities (Wright et al., 2016; Abbott et al., 2018). For example, municipal solid wastes contain animal manure, which allows the growth of some bacteria species that agricultural and vegetable domestic residues do not have (Anastasi et al., 2004).

As it can be seen so far, wastes are an available and low-cost source to produce organic amendments and biofertilizers; whereby, cities located in tropical climate might carry out managing programs of domestic organic wastes to produce organic amendments, taking advantage of the high environmental humidity and the high temperature, as well as its high availability of plant debris and humus. But, notwithstanding the foregoing, it is necessary to carry on studying the effectiveness of these organic amendments in order to define with precision the adequate quantity and frequency to be able to apply them to different crops using local bacteria and fungi. Therefore and as can be seen: this work aims to evaluate the effect of three organic amendments, made of vegetable domestic wastes and humus, by fermentation and composting; on the growth of sorghum and 
measuring precisely plant height and productivity variables.

\section{MATERIALS AND METHODS}

\section{Bioreactors}

As for method and materials with respect to bioreactors, the procedure was as follows:

Four polyethylene, cylindrical containers of $220 \mathrm{~L}$ capacity and hermetic closing $(56 \mathrm{~cm}$ diameter $\mathrm{x} 910$ $\mathrm{cm}$ height) were used as bioreactors in a greenhouse. Two bioreactors were made up for fermentation process with gas exit, water trap and pressure indicator; while two bioreactors for aerobic decomposition (composting) were made up with two pipelines as respirators from top to bottom.
To obtain humus, plant debris biomass from agriculture and gardening were composted by biopile for a fixed time period of one year at Loma Bonita [State of Oaxaca, Mexico; coordinates $18^{\circ} 06^{\prime} 06.3^{\prime \prime} \mathrm{N}$, $\left.95^{\circ} 53^{\prime} 48.9^{\prime \prime} \mathrm{W}\right]$, under tropical climate, with average temperature $25.0^{\circ} \mathrm{C}$ and $80 \%$ humidity.

An effective volume of work about $80 \mathrm{~kg}$ fresh biomass was placed in each bioreactor, according to a proportion of $50 \%$ of vegetable domestic wastes and $50 \%$ of humus, and liming with $500 \mathrm{~g} \mathrm{CaCO} 3$. Domestic wastes with lixiviates and humus were mixed and poured into the containers, where the maximum-minimum temperature and $\mathrm{pH}$ were measured for 60 days. The three treatments are shown in Table 1.

Table 1. Substrates and process used in bioreactors. Loma Bonita, Oaxaca, Mexico.

\begin{tabular}{ccccc}
\hline Bioreactor & Biomass source & Treatment & InitialpH & FinalpH \\
\hline S & DVD + humus & Solid aerobic decomposition & 7.0 & 7.3 \\
( composting) & Liquid fermentation & 5.0 & 6.5 \\
LM & DVD + humus & Liquid fermentation & 8.0 & 6.5 \\
\hline
\end{tabular}

DVD, vegetable domestic wastes. DMS, dry maize agricultural waste. The $\mathrm{pH}$ of vegetable domestic wastes lixiviates was 4.9. Composting mix was manually turned at 15 -day intervals.

\section{Fertilization test on sorghum}

In relation to the method and materials of the fertilization test on sorghum, the procedure was as follows:

The bioassay was conducted on a land plot $(15 \times 30 \mathrm{~m})$ at Loma Bonita, from June to August 2017 for 90 days. Fertilization was applied under randomized block design with one factor (fertilization treatment) to onemonth-age sorghum plants. Four treatments were assessed in three experimental units for each one. The experimental unit had $25.6 \mathrm{~m} 2$ with four furrows $8 \mathrm{~m}$ longitude separated $80 \mathrm{~cm}$ each other. The two fermented organic amendments, compost and NPK fertilizer (control) were applied in unique dose as follow: fertilizer control with $0.5 \mathrm{~kg}$ urea and $0.222 \mathrm{~kg}$ diamonic phosphate (DAP) per experimental unit, where the final concentration of $\mathrm{N}$ and $\mathrm{P}$ applied to the control treatment was $10.28 \mathrm{~g} \mathrm{~m}-2$ and $3.95 \mathrm{~g} \mathrm{~m}-2$, respectively; the treatments $\mathrm{S}$ and $\mathrm{L}$ with $40 \mathrm{~kg}$ or liters of compost and organic amendments per experimental unit, respectively; and the treatment LM with $26 \mathrm{~L}$ of organic amendment per experimental unit (Figure 1). Finally, plant height and fresh weight ( $\mathrm{kg} \mathrm{m}-1$ of furrow) were recorded from representative samples at the end of the test period. Data were statistically analyzed with the R 3.4.1 software, using ANOVA and Tukey test $(\mathrm{p} \leq 0.05)$ to find out significant differences between the distinct treatments. 

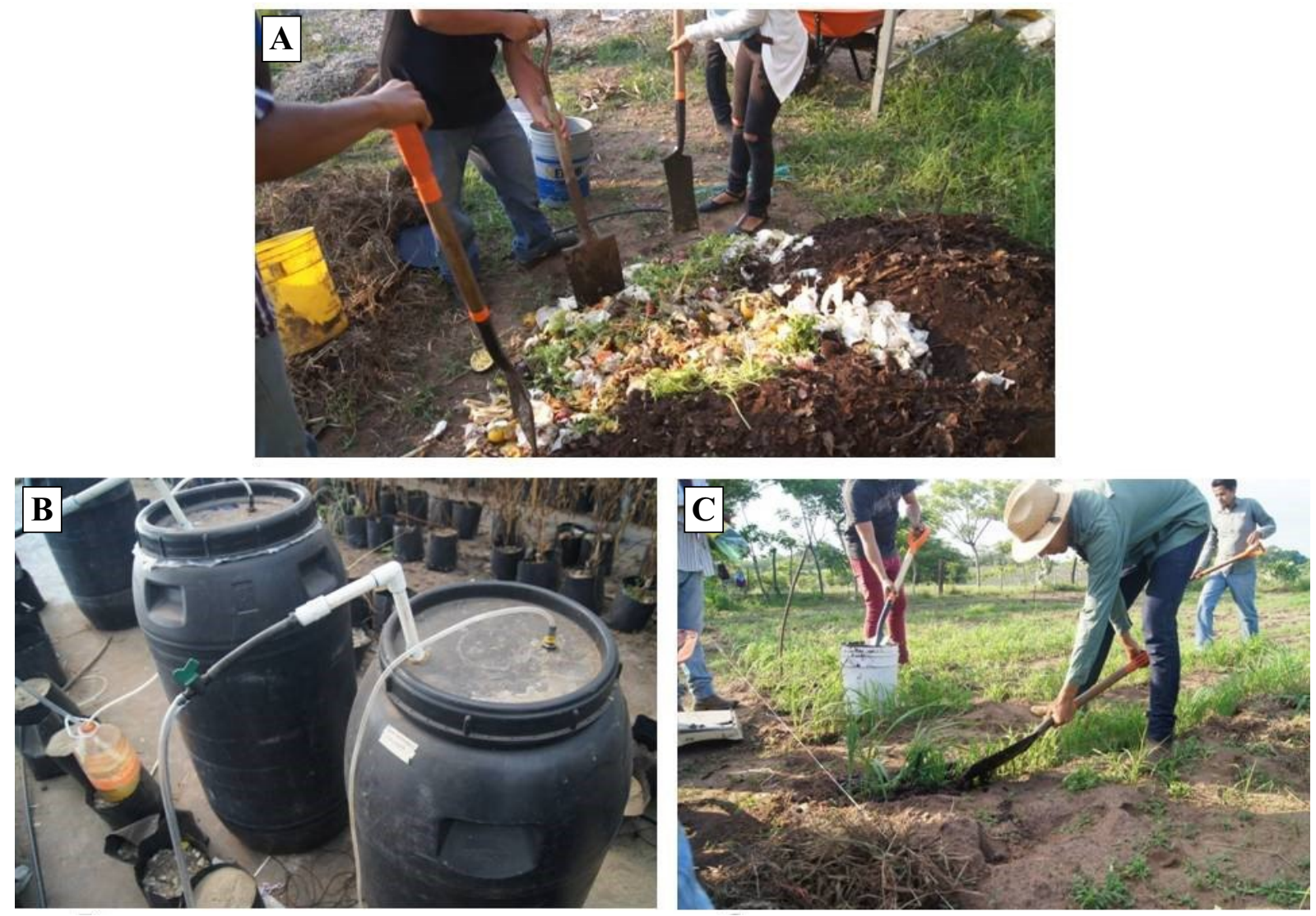

Figure 1. Implemented methodology. A, Vegetable domestic wastes and humus used as substrates in bioreactors. B, Bioreactors for fermentation. C, Application of organic amendments on sorghum plants.

\section{RESULTS}

After carrying out our study, we obtained the following results:

The greenhouse temperature during fermentation and composting process was the highest recorded in the year (Figure 2). Consistent and optimum $\mathrm{pH}$ of compost and fermented organic amendments $\mathrm{L}$ and LM were attained in 52 days. Compost $\mathrm{S}$ showed a noticeable mycelium presence at that time, but they were not identified yet in this work.

Sorghum plant height, obtained with organic amendments L and LM, was not different to those obtained by the control treatment. Moreover, Tukey analysis showed the highest yield was obtained with compost $\mathrm{S}$ (Table 2).
Table 2. Fresh weight and plant height on sorghum (Sorghum bicolor L. Moench)

\begin{tabular}{ccc}
\hline Treatment & $\begin{array}{c}\text { Mean biomass } \\
(\mathrm{kg} / \mathrm{m})\end{array}$ & $\begin{array}{c}\text { Mean plant } \\
\text { height }(\mathrm{cm})\end{array}$ \\
\hline $\mathrm{C}$ & $0.460^{\mathrm{b}}$ & $51.400^{\mathrm{bc}}$ \\
$\mathrm{S}$ & $0.876^{\mathrm{a}}$ & $75.100^{\mathrm{a}}$ \\
$\mathrm{L}$ & $0.428^{\mathrm{b}}$ & $58.417^{\mathrm{b}}$ \\
$\mathrm{LM}$ & $0.279^{\mathrm{b}}$ & $43.933^{\mathrm{c}}$ \\
\hline
\end{tabular}

C, control. S, compost. L, liquid organic amendment from domestic wastes. LM, liquid organic amendment from dry maize agricultural wastes. Means in a column with different uppercase letters are statistically different $(\mathrm{p} \leq 0.05)$. 


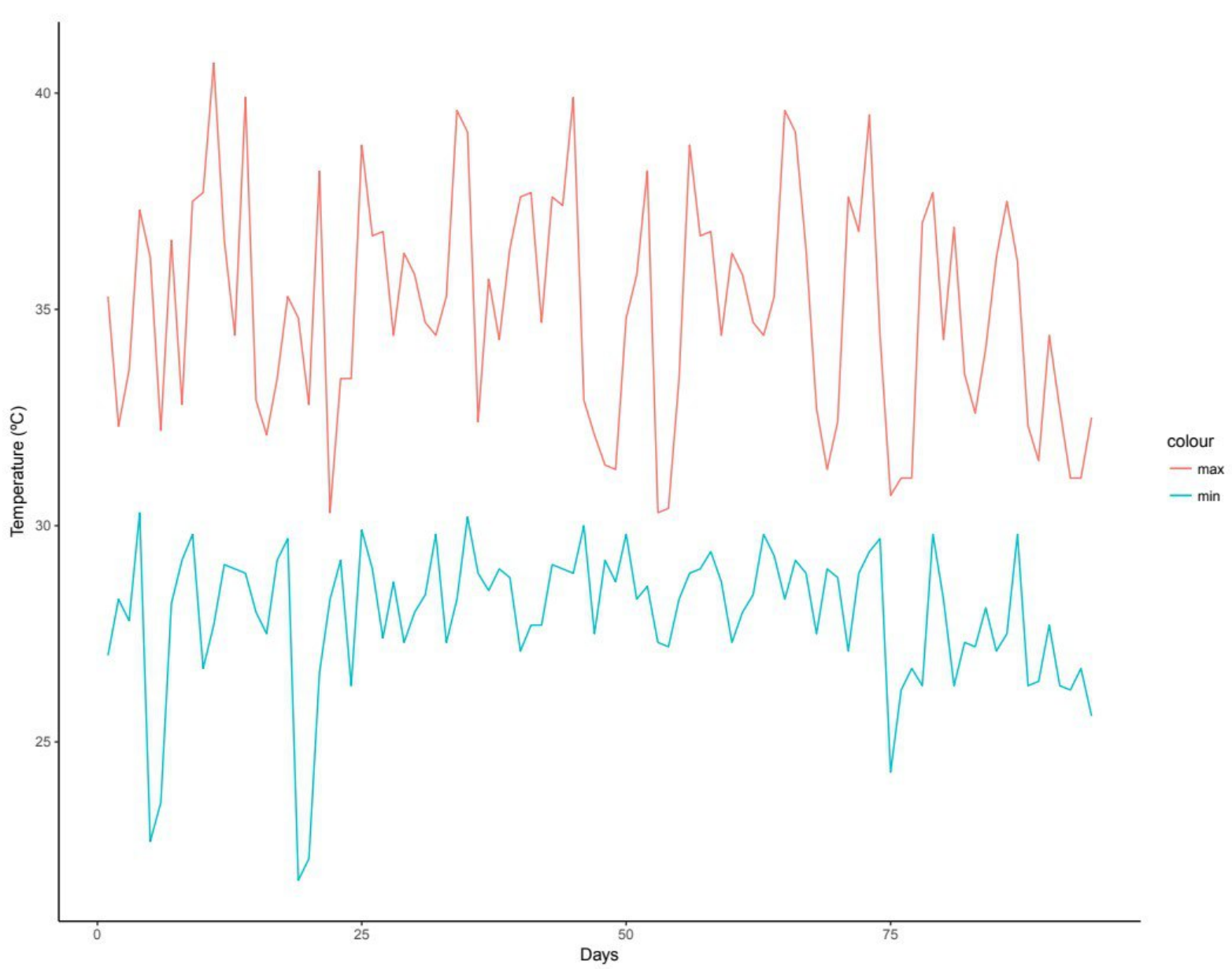

Figure 2. Greenhouse temperature $\left({ }^{\circ} \mathrm{C}\right)$ during the fermentation and composting period in Loma Bonita, Oaxaca, Mexico.

\section{DISCUSSION}

After the study, it was observed that plant height obtained with compost $\mathrm{S}$ was significantly the highest of treatments. Altuhaish and Tjahjoleksono (2014) reported similar results using compost and solid and liquid bioferilizers with Azotobacter sp., Azospirillium sp., Pseudomonas sp., and Bacillus sp. on tomato plants (Lycopersicon esculentum); they observed plant height and yield (kg per land plot) were higher than those obtained with chemical fertilizer. For its part, Hipolito-Romero et al. (2017) indicated that there were not statistical differences in plant height between biofertilizers and chemical fertilizer used in two-months-old plants of Theobroma cacao; but it was higher when plants attained twelve-months-old. They mentioned that bacterial consortiums improve soil fertility, because the regulation of biogeochemical cycles increases the availability of nutrients, the activation or inhibition of microbial enzymes and the degradation process.

Coupled with this, Garcia-Olivares et al. (2012) used three native strains of Azospirillum brasilense, isolated from North of Mexico, as biofertilizers in sorghum obtaining an increase about $500-700 \mathrm{~kg} / \mathrm{ha}$ of dry yield in contrast with chemical fertilization. Therefore, we consider that compost $\mathrm{S}$ contains native microbiome which was enriched during compost process, mainly due to the fact that we used humus from plant debris from local soil; thereby enabling it would be possible to use it better than manure as microbial source.

On the other hand, the wide diversity of the microbial community within compost during the decomposition process involves many interactions among different functional groups of bacteria and fungi. In its earlier stages, the degradation of materials like cellulose and lignine is carried out by some species that allows a microbial succession, giving rise to other important 
species for the plant in the latest stages, when compost's maturation occurs (Anastasi et al., 2004; Agrawal, 2014; Romero-Yam et al., 2015). Where it follows that we consider that good results obtained with compost $\mathrm{S}$ were caused by its nutrient and native microbial diversity content which is adapted to local conditions. Consequently, research continuation is necessary in order to know the amount and frequency supply of these organic fertilizers; and also, to identify bacteria and fungi in soil and plant rhizosphere.

In regard to the chemical composition of compost, the nitrogen amount into compost $\mathrm{S}$ was about $1 \%$, similar to $>2 \%$ reported for compost, by Smith and Collins (2007), as well as Van den Berghe and Hue (1999) and Viti et al. (2010); whereas Romero-Yam et al. (2015) obtained 3.4 to $4.7 \%$ of total nitrogen in compost from the filter cake reactivated with chicken manure. As can be seen the nitrogen amount in compost and others organic amendments is diverse, from $0.4 \%$ in vegetable wastes up to $7 \%$ in some manures, for this reason, it is possible approaching the compost amount that might be used in further studies. Even more, the $\mathrm{pH}$ of the compost $\mathrm{S}$ was considered an advantage since it was optimum despite that the lixiviates of domestic vegetable waste were more acid. This compost $\mathrm{S}$ had a $\mathrm{pH}$ as favourable as the compost enriched with chicken manure, reported by RomeroYam et al. (2015), or the organic urban waste compost, recorded by Viti et al. (2010).

Also, the temperature had an important effect over composting process in this work. The tropical clime where this study was carried out allowed the maturation of compost in 52 days. Among other cases, Romero-Yam et al. (2015) used a composting method in sub-humid climate, where the range of temperature was between 38.2 and $-1.6^{\circ} \mathrm{C}$ maximum and minimum, respectively for a time period of 87 days. As a result of these conditions, they observed the highest growth of bacteria and fungi populations was reached from 45 days up to 87 days. Van den Berghe and Hue (1999) obtained pit compost for a time period of 90 days in a tropical climate, while Singh and Sharma
(2003) got composting in 30 days under similar conditions.

In general, we can affirm that composting was the best method to obtain organic amendments with domestic wastes and humus. Nevertheless, it is necessary to know microbial dynamic during the process, in the soil and rhizosphera. In this way, some bacteria and fungi could be identified and isolated to enrich compost and improve the results obtained in this work. Last but not least important, some molecular tools as metagenomics and metatranscriptomics could be useful to understand and identify the relationship between microbial communities in these conditions (Carvalhais et al., 2012).

\section{CONCLUSIONS}

Finally, based on our research done, we can conclude that this preliminary test on fertilization of sorghum showed that the compost $\mathrm{S}(75.10 \pm 21.12 \mathrm{~cm}$ and $0.876 \pm 0.162 \mathrm{~kg} / \mathrm{m}$ ) was more efficient than liquid organic amendments $\mathrm{L}(58.41 \pm 17.75 \mathrm{~cm}$ and $0.428 \pm$ $0.139 \mathrm{~kg} / \mathrm{m})$ and $\mathrm{LM}(43.93 \pm 14.01 \mathrm{~cm}$ and $0.279 \pm$ $0.040 \mathrm{~kg} / \mathrm{m}$ ) produced by fermentation and the chemical fertilizer C $(51.40 \pm 19.30 \mathrm{~cm}$ and $0.460 \pm$ $0.22 \mathrm{~kg} / \mathrm{m})$.

Also and a consequence of our study that we have carried out, we can affirm and establish that biological decomposition process was favoured by tropical climatic conditions to produce this kind of organic amendments in a short time-frame (52 days). Finally we ratify here: vegetable domestic wastes and humus are a good option as substrate to produce compost due to their high availability and low cost.

\section{BIBLIOGRAPHIC REFERENCES}

Abbott, L. K., L. M. Macdonald, M. T. F. Wong, M. J. Webb, S. N. Jenkins, and M. Farrell. 2018. "Potential roles of biological amendments for profitable grain production - A review". Agric. Ecosys. Environ. 256:34-50

Agrawal, P. K. 2014. "Microbial ecology of compost ecosystem: with special reference to 
mushroom compost”. J. Biol. Sci. Opin. 2: 4550

Altuhaish, A. H., and A. Tjahjoleksono. 2014. "Biofertilizer effects in combination with different drying system and storage period on growth and production of tomato plant under field conditions". Emir. J. Food Agric. 26: 716-722

Anastasi, A., G. C. Varese, S. Voyron, S. Scannerini, and V. F. Marchisio. 2004. "Characterization of fungal biodiversity in compost and vermicompost”. Compost Sci. Utiliz. 12: 185191

Carvalhais, L. C., P. G. Dennis, G. W. Tyson, and P. M. Schenk. 2012 . "Application of metatranscriptomics to soil environments". $J$. Microbiol. Methods. 91:246-251

García-Olivares, J. G., V. R. Moreno-Medina, I. C. Rodríguez-Luna, A. Mendoza-Herrera, y N. Mayek-Pérez. 2006. "Biofertilización con Azospirillum brasilense en sorgo, en el norte de México". Agric. Téc. Méx. 32: 135-141

García-Olivares, J. G., A. Mendoza-Herrera, y N. Mayek-Pérez. 2012. "Efecto de Azospirillum brasilense en el rendimiento del maíz en el norte de México". Universidad y Ciencia. 28: $79-84$

Hipólito-Romero E., M. G. Carcaño-Montiel, J. M. Ramos-Pradoa, E. A. Vázquez-Cabañas, L. López-Reyes, y J. Ricaño-Rodrigueza, 2017. "Efecto de inoculantes bacterianos edáficos mixtos en el desarrollo temprano de cultivares mejorados de cacao (Theobroma cacao L.) en un sistema agroforestal tradicional del norte de Oaxaca, México". Rev. Argent. Microbiol. 49: 356-365

Igiehon, N. O., and O. O. Babalola. 2017. "Biofertilizers and sustainable agriculture: exploring arbuscular mycorrhizal fungi". Appl. Microbiol. Biotechnol. 101:4871-4881

Radha, T. K., and D. L. N. Rao. 2014. "Plant growth promoting bacteria from cow dung based biodynamic preparations". Indian $J$. Microbiol. 54: 413-418

Romero-Yam L. A., J. J. Almaraz-Suarez, J. VelascoVelasco, A. Galvis-Spinola, and F. GaviReyes. 2015. "Microbial dynamics during composting of filter cake reactivated with chicken manure". Rev. Chapingo Serie Hortic. 21:21-31.

Singh, A., and S. Sharma. 2003. "Effect of Microbial Inocula on Mixed Solid Waste Composting, Vermicomposting and Plant Response". Compost Sci. Utiliz. 11: 190-199

Smith, J. L., and H. P. Collins. 2007. "Management of organisms and their processes in soils". In: Soil Microbiology, Ecology, and Biochemistry. Eldor, A. P. (ed). Oxford (UK): Academic Press.

Van den Berghe, C. H., and N. V. Hue. 1999. "Liming potential of composts applied to an acid oxisol in Burundi”. Compost Sci. Utiliz. 7: 40-46

Vessey, J. K. 2003. "Plant growth promoting rhizobacteria as biofertilizers". Plant and Soil. 255: 571-586

Viti, C., E. Tatti, F. Decorosi, E. Lista, E. Rea, M. Tullio, E. Sparvoli, and L. Giovannetti. 2010. “Compost effect on plant growth-promoting rhizobacteria and mycorrhizal fungi population in maize cultivations". Compost Sci. Utiliz. 18: 273-281

Wright, C., A. P. Gryganskyi, and G. Bonito. 2016. "Fungi in composting". In: Fungal Applications in Sustainable Environmental Biotechnology. Fungal Biology Series. Purchase, D. (ed). Cham (Switzerland): Springer International Publishing. 